Yüzüncü Y1l Üniversitesi
Tarim Bilimleri Dergisi

Araştırma Makalesi

\title{
Kiraz Dış Ticaretindeki Gelişmeler ve Türkiye'nin Karşılaştırmalı Üstünlüğü
}

\section{Zerrin ÇELİK ${ }^{* 1}$, Hakan SAÇTI ${ }^{2}$, Hakan ADANACIOĞLU ${ }^{3}$}

${ }^{1}$ Uluslararası Tarımsal Araştırma ve Eğitim Merkezi Tarım Ekonomisi Bölümü, 35660, İzmir, Türkiye ${ }^{2}$ Tarımsal Araştırmalar ve Politikalar Genel Müdürlüğü Tarım Ekonomisi Bölümü, 06800, Ankara, Türkiye

${ }^{3}$ Ege Üniversitesi Ziraat Fakültesi Tarım Ekonomisi Bölümü, 35100, İzmir, Türkiye *Sorumlu yazar e-posta: zrcelik67@gmail.com

\section{Makale Bilgileri}

Geliş: 25.10 .2018

Kabul: 28.02.2019

Online Yayınlanma 31.05.2019

DOI: $10.29133 /$ yyutbd.474794

\section{Anahtar kelimeler}

Dünya,

İhracat ve ithalat,

Rekabet gücü,

Türk kiraz sektörü
Öz: Küresel kiraz talebi artmaktadır ve pazar büyümektedir. Türkiye kiraz ihracatında genellikle üçüncü en büyük ülke konumundadır. Bu çalışmanın amac1, uluslararası ticarette Türk kiraz sektörünün rekabet gücünü analiz etmektir. Çalışmada Balassa'nın Açıklanmış Karşılaştırmalı Üstünlükler (RCA) endeksi ve Vollrath'ın endeksleri kullanılmıştır. 2001-2017 dönemini kapsayan analizler için kullanılan kiraz ticaret verileri, Uluslararası Ticaret Merkezi veri tabanından elde edilmiştir. Bu amaçla dünyanın en büyük ihracatçı ülkeleri olan Şili, Amerika Birleşik Devletleri (ABD), Hong Kong, Türkiye, İspanya, Avusturya, Özbekistan, Yeni Zelanda, Kanada, Yunanistan, Hollanda, İtalya ve Avustralya incelenmiştir. 2001-2017 döneminde Türkiye kiraz ihracatı ortalama 124 milyon dolar olarak gerçekleşmiştir. İhracat yapılan ülkelerin payları incelendiğinde; $\mathrm{AB}$ ülkeleri önemli bir pazardır. Ayrıca son on yıldır Rusya Federasyonu da Türkiye için önemli bir ülke konumuna gelmiştir. Hesaplanan Balassa ve Vollrath endekslerine göre; Türkiye kiraz ihracatında büyük bir karşılaştırmalı üstünlüğe sahiptir. Bununla birlikte, Türkiye'nin karşılaştırmalı üstünlüğü son yıllarda nispeten azalmaktadır. Bu açıdan bakıldığında, mevcut pazar taleplerinin yanında yeni pazarlara ulaşmak da çok önemlidir.

\section{Trends in Foreign Trade of Cherry and Turkey's Comparative Advantage}

\section{Article Info}

Received: 25.10 .2018

Accepted: 28.02 .2019

Online Published 31.05.2019

DOI: $10.29133 /$ yyutbd.474794

\section{Keywords}

World,

Export and import,

Competitiveness,

Turkish cherry sector

\begin{abstract}
Global cherry demand has increased and the market has grown. Turkey is the third largest exporter country in the world for cherry. The objective of this study is to analyze the Turkish cherry sector's competitive power in international trade. In the study, Balassa's Revealed Comparative Advantage (RCA) and Vollrath's indexes were used. The cherry trade data is obtained from the International Trade Center (ITC-TRADEMAP) database and calculated for the years between 2001-2017. For this purpose, the Chile, USA, Hong Kong, China, Turkey, Spain Austria, Uzbekistan, New Zealand, Canada, Greece, Netherlands, Italy and Australia were taken into account as the most exporter countries in the world. Turkey's world cherry export is around 124 million dollars on avarage for the period of 2001-2017. When the shares of the exporting countries are examined; EU countries seem to be a significant market. At the same time, The Russian Federation for the last ten years has become an important country for Turkey. According to calculated Balassa's and Vollrath's indexes, Turkey has a significant comparative advantage in the cherry export. However, Turkey's comparative advantage has relatively been decreasing in recent years. From this point of view, it is very important to develop new markets for existing market demands.
\end{abstract}




\section{Giriş}

Küreselleşme ile birlikte rekabet olgusu da her geçen gün ağırlığını hissettirmektedir. Ülkeler, uluslararası pazarlardaki paylarını artırabilmek için rekabet güçlerini artırmaya çabalamaktadır. Türkiye sahip olduğu avantajlar ile başta meyve olmak üzere birçok tarımsal ürünün üretiminde dünyada ilk sıralarda yer almaktadır.

Türkiye 2017 yılı rakamlarıyla, dünya yaş meyve üretiminde \%2.2'lik payla 8. sırada yer alırken, kiraz üretiminde $\% 26$ paya sahiptir ve yaklaşı 627 bin ton üretim ile lider konumdadır (FAO, 2018). Kiraz ithalatı yok denecek kadar az olan Türkiye'de üretilen kirazın yaklaşık \%10'u ihraç edilmektedir. İhracat oranının düşük olması, kiraz üretimindeki yüksek potansiyelin ihracata tam yansıtılamadığını göstermektedir.

Küresel kiraz talebi artmıştır. Pazar değeri, 2001 yılına göre yaklaşık 1.9 milyar dolar büyümüştür. En büyük ithalatçı ülkeler Çin, Hong Kong ve Rusya'dır (Çelik ve Gökkür 2018).

Dünyada kiraz ihracatında büyük bir rekabet bulunmaktadır. Söz konusu rekabet, ilk onda yer alan; Şili, ABD, Hong Kong, Türkiye, İspanya, Avusturya, Özbekistan, Yeni Zelanda, Kanada ve İtalya arasında yaşanmaktadır.

Bu çalışma, Türk kiraz sektörünün 2001-2017 dönemi için uluslararası ticaretteki rekabet gücünü ortaya koymayı amaçlamaktadır. Türkiye'nin kiraz üretim durumu ve dış ticareti incelenerek rakip ülkelerle birlikte kiraz sektörünün rekabet gücü analiz edilmiştir. Analizlerde Balassa'nın ve Vollrath'ın geliştirmiş oldukları endeksler kullanılmıştır.

\section{Materyal ve Yöntem}

Kiraz sektöründe rekabet edilebilirliğin ortaya konulması için analizlerde kullanılan makro veriler bu çalışmanın ana materyalini oluşturmuştur. Kullanılan veriler 2001-2017 dönemini kapsamaktadır. Üretim ve dikim alanlarına ait veriler BM Gıda ve Tarım Örgütü (FAO); ticarete yönelik veriler ise Uluslararası Ticaret Merkezi (ITC-TRADE MAP) veri tabanından elde edilmiştir.

Dünyadaki en güvenilir kaynaklardan biri olarak kabul edilen ITC, birçok ülkenin istatistik kurumlarından gelen Gümrük Tarife İstatistik Pozisyon numarası (GTïP) şeklindeki verilerini derleyip, güncel veri tabanını oluşturmaktadır. Dünya Gümrük Örgütü (WCO) 2012 yılından bu tarafa kirazın GTIP numarasını değiştirmiştir. Türkiye'de aynı GTïP numarası kullanılmaktadır. Bu kapsamdaki çalışmada; 2011 yılı ve öncesine yönelik veriler "080920"; 2012 yılından sonrası ise “080929” GTIP numarası ile derlenmiştir.

$\mathrm{Bu}$ çalışmada Türk kiraz sektörünün rekabet gücünü analiz etmek amacıyla Balassa'nın Açıklanmış Karşılaştırmalı Üstünlükler (RCA) endeksi ve Vollrath'ın endeksleri kullanılmıştır. Rekabet analizi için, Türkiye ile aynı dönemde ve önemli miktarda ihracat yapan ülkeler rakip olarak ele alınmıştır.

Açıklanmış Karşılaştırmalı Üstünlükler (RCA) endeksi, 1965'te Bela Balassa tarafından geliştirilen ve rekabet gücünün sayısal olarak belirlenmesinde yaygın olarak kullanılan yöntemlerden biridir (Laursen, 1998). Balassa'nın RCA yaklaşımı, ülkenin bir sektördeki yurt içi uzmanlaşmasını, dünyanın uzmanlaşmasıyla karşılaştırır. Bu yaklaşım, karşılaştırmalı üstünlügüun gerçek biçiminin ticaret sonrası verilerden gözlemlenebileceğini varsaymaktadır. Balassa Endeksinin hesaplanmasında;

RCAij= $(x i j / X j) /(x i w / X w)$ eşitliği kullanılmıştır.

Burada RCAij; j ülkesinin i malı için açıklanmış karşılaştırmalı üstünlükler endeksini göstermektedir. xij: j ülkesinin i malı ihracatı, Xj: $\mathrm{j}$ ülkesinin toplam ihracatı, xiw: i malı dünya ihracat değeri, Xw: dünya toplam ihracat değerini ifade etmektedir. Balassa Endeksinin 1'den büyük çıkması, j ülkesinin i malında karşılaştırmalı üstünlüğe sahip olduğunu ve uzmanlaştığını göstermektedir. Yani, o malın ülkenin toplam ihracatı içindeki payı, dünya ticaretindeki payından daha büyüktür. $R C A<1$ durumunda ise, o malda karşılaştırmalı dezavantaja sahip olunduğu ve uzmanlaşılamadığı anlaşılmaktadır (Balassa, 1965).

Balassa endeksinin sadece ihracat büyüklügünü dikkate alması eleştirilmiştir. Bu nedenle Vollrath Balassa endeksine alternatif üç ölçüm yöntemi geliştirmiştir. Vollrath'a göre endeksin hesaplanmasında ihracat ile birlikte ithalat değerleri de hesaba katılmalıdır. Bu ölçümlerden ilki Göreli 
İhracat Avantajı (RXA) endeksidir. Göreli İhracat Avantaj1 endeksi, belirli bir üründe herhangi bir ülkenin dünya piyasalarında sahip olduğu ihracat payının diğer bütün mallarda dünya ihracatında sahip olduğu paya oranı olarak tanımlanabilir (Frohberg ve Hartmann, 1997). Endeksin bu özelliği ile ele alınan ülke ve malları, dünya toplam ihracatının hesaplanmasında dışta tutulmakta ve böylelikle ele alınan ülke ve malın hesaplamaya iki kez dâhil edilmesi engellenmektedir (Akhtar ve ark., 2013). Vollrath'ın RXA endeksi şöyle formüle edilmektedir (Vollrath, 1991):

$$
\text { RXAij= }(X i j / X n j) /(X i r / X n r)
$$

Burada RXAij: j ülkesinin i malında göreli ihracat avantajını ifade etmektedir. X: ihracatı, n: geri kalan tüm malları ve r: dünyanın geri kalanını göstermektedir.

Göreli İthalat Nüfuz (RMP) endeksi, belli bir sektörün ithalatının o ülke ithalatı içindeki payının, o sektörün dünyadaki ithalatının dünya toplam ithalatındaki payına oranıdır.

$$
\mathrm{RMPij}=(\mathrm{mij} / \mathrm{Mj}) /(\mathrm{miw} / \mathrm{Mw})
$$

mij: $\mathrm{j}$ ülkesinin i malı ithalatı, mj: $\mathrm{j}$ ülkesinin toplam ithalat1, Miw: i malı dünya ithalat değeri, Mw: dünya toplam ithalat değerini ifade etmektedir. Eğer endeks değeri 1'den büyükse rekabetçi dezavantajın, l'den küçükse rekabetçi avantaj var demektir.

Vollrath'ın ikinci ölçüm yöntemi Göreli Ticari Avantaj (RTA) endeksi olup, Göreli İhracat Avantajı (RXA) ile Göreli İthalat Nüfuz (RMP) endeksi arasındaki fark olarak hesaplanmaktadır.

$$
\text { RTAij= RXAij-RMPij }
$$

$\mathrm{Bu}$ endeks ile ortaya konulan rekabet avantajı, göreli ihracat ve ithalat avantajlarının önemi ile ağırlıklandırılan bir göstergedir. Böylece ilgili malın ihracatına veya ithalatına ilişkin çok küçük değerlerin endeks üzerinde etkili olması söz konusu olmamaktadır. Pozitif bir değer rekabetçi avantaja, negatif bir değer ise dezavantaja karşıllk gelmektedir (Frohberg ve Hartmann, 1997; Aynagöz Çakmak, 2005). Üçüncü yöntem ise Göreli Rekabet Üstünlüğü (RC) endeksidir. j ülkesinin i malında göreli rekabet üstünlüğü endeksini göstermektedir. Endeks şu şekilde gösterilmektedir:

$$
\text { RCij= Ln(RXAij)-Ln(RMPij) }
$$

Vollrath, RC endeksinin arz ve talep dengesini içerdiği için daha tercih edilebilir bir endeks olduğunu belirtmektedir. Çünkü RC endeksi, bir ülke veya malın karşılaştırmalı üstünlüğünü daha iyi yansıtmaktadır. Ancak iki yanlı ticaretin söz konusu olmadığı durumlarda (ithalat ya da ihracat yoksa), endeksin uygulanması sınırlı kalmaktadır.

$\mathrm{Bu}$ üç endeks birlikte ele alındığında Vollrath, RXA endeksinin uygulamada daha yaygın kullanıldığını kabul etmektedir. RXA, RTA, RC endekslerinin pozitif değerler alması karşıllaştırmalı avantajı, negatif değerler alması ise karşılaştırmalı dezavantajı göstermektedir (Vollrath, 1991).

\section{Bulgular}

\subsection{Dünya kiraz üretimi}

Dünya kiraz üretim alanları ve miktarı yıllar itibariyle artış göstermektedir. 2001-2017 yılları arasındaki gelişmeler incelendiğinde; dalgalanmalar olmakla birlikte dikim alanı \%24 artarak 416445 milyon hektar olmuştur. Üretim miktarı ise \%34 artarak 1.8 milyon tondan 2.4 milyon tona ulaşmıştır (Şekil 1). 

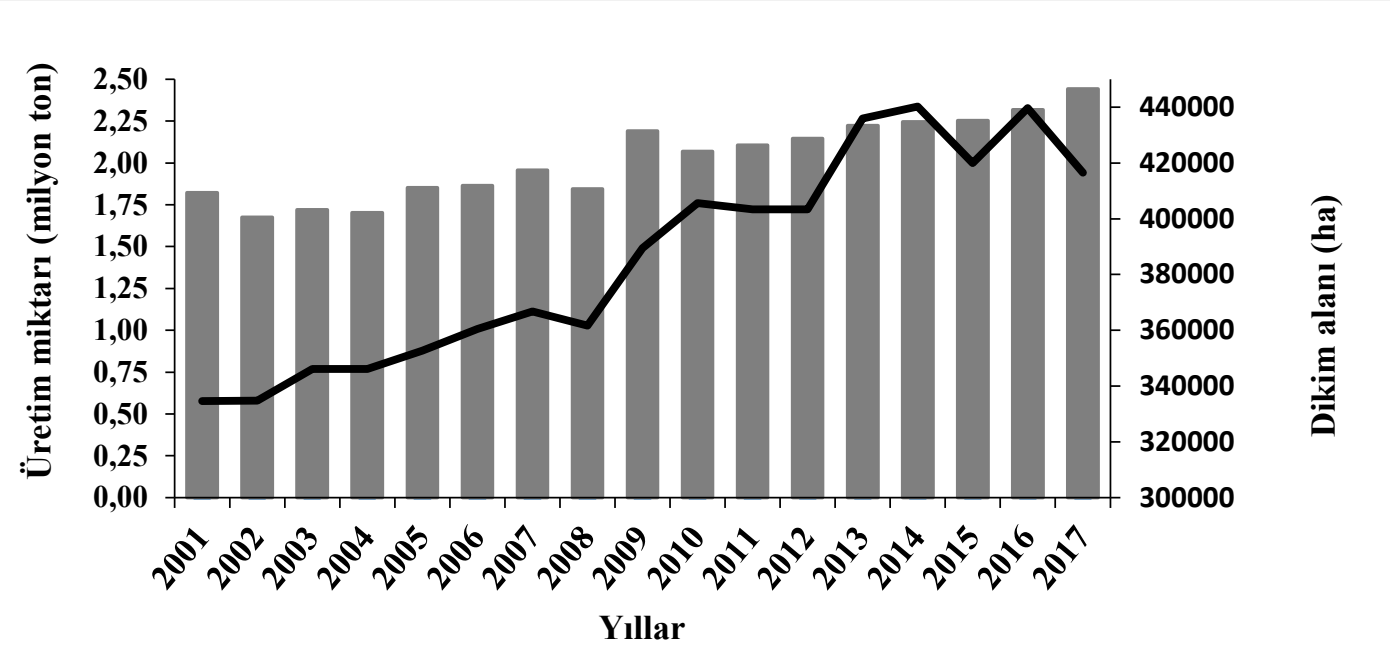

Şekil 1. Dünya kiraz üretim alanı ve miktarı durumu. (FAO veri tabanı, 2018).

Dünyada önemli kiraz üreticisi ülkelerin 2001-2016 yılları arasındaki üretim miktarlarındaki değişim "Çizelge 1." de gösterildiği gibidir. Türkiye, Şili, Özbekistan ve Yunanistan üretim bakımından son on beş yılda önemli artışlar gösteren ülkelerdir. Türkiye'nin üretimi yaklaşık iki kattan fazla, Şili'nin üretimi ise beş kat artmıştır. Almanya, Rusya Federasyonu, Fransa, Romanya ve İtalya'da (sırasıyla \%79, \%48, \%37, \%19 ve \%15) ise önemli derecede düşüş görülmüştür.

Çizelge1. Önemli kiraz üreticisi ülkelerin üretim miktarları (Bin ton)

\begin{tabular}{|c|c|c|c|c|c|c|c|c|c|c|c|c|c|c|c|c|}
\hline Ülkeler & 2001 & 2002 & 2003 & 2004 & 2005 & 2006 & 2007 & 2008 & 2009 & 2010 & 2011 & 2012 & 2013 & 2014 & 2015 & 2016 \\
\hline Türkiye & 250.0 & 210.0 & 265.0 & 245.0 & 280.0 & 310.3 & 398.1 & 338.4 & 417.7 & 417.9 & 438.6 & 470.9 & 494.3 & 445.6 & 535.6 & 599.7 \\
\hline ABD & 209.0 & 164.6 & 160.8 & 256.8 & 227.5 & 266.3 & 281.9 & 225.1 & 401.8 & 284.1 & 303.4 & 384.6 & 301.3 & 329.9 & 307.0 & 288.5 \\
\hline İran & 218.6 & 653.9 & 225.1 & 174.6 & 224.9 & 268.8 & 247.1 & 215.4 & 208.4 & 228.1 & 244.9 & 253.5 & 279.4 & 134.0 & 136.0 & 220.4 \\
\hline İtalya & 111.0 & 126.0 & 102.0 & 95.2 & 101.3 & 110.9 & 106.2 & 134.4 & 116.2 & 115.5 & 112.8 & 104.8 & 131.2 & 110.8 & 111.1 & 94.9 \\
\hline İspanya & 85.6 & 113.1 & 105.7 & 81.3 & 92.6 & 88.2 & 73.2 & 69.7 & 97.6 & 85.2 & 101.9 & 96.9 & 97.2 & 118.2 & 94.1 & 94.1 \\
\hline Romanya & 91.2 & 66.3 & 98.5 & 51.0 & 117.9 & 104.8 & 65.2 & 67.7 & 67.9 & 70.3 & 81.8 & 70.5 & 80.5 & 82.8 & 75.5 & 73.8 \\
\hline Rusya Fed. & 88.0 & 85.0 & 90.0 & 100.0 & 93.0 & 50.0 & 100.0 & 73.0 & 76.0 & 66.5 & 76.0 & 72.0 & 78.0 & 77.0 & 41.6 & 46.1 \\
\hline Almanya & 139.9 & 70.0 & 33.4 & 39.1 & 27.9 & 31.6 & 34.5 & 25.2 & 39.5 & 30.8 & 37.0 & 23.0 & 24.5 & 39.6 & 31.4 & 29.4 \\
\hline Ukrayna & 54.9 & 72.5 & 73.8 & 85.3 & 100.2 & 48.9 & 68.2 & 74.7 & 53.0 & 73.0 & 72.8 & 72.6 & 81.2 & 67.3 & 76.6 & 63.3 \\
\hline Fransa & 55.4 & 64.7 & 52.6 & 58.2 & 62.9 & 65.5 & 45.8 & 40.4 & 53.6 & 44.1 & 45.1 & 27.8 & 35.8 & 47.3 & 41.7 & 34.7 \\
\hline Şili & 28.0 & 29.0 & 29.5 & 32.0 & 32.0 & 41.0 & 45.0 & 70.4 & 41.1 & 60.4 & 85.8 & 71.5 & 81.0 & 84.9 & 103.4 & 123.2 \\
\hline Özbekistan & 20.5 & 21.4 & 19.5 & 14.5 & 22.0 & 53.6 & 55.0 & 61.0 & 67.0 & 75.0 & 56.5 & 62.0 & 70.0 & 80.0 & 90.0 & 95.3 \\
\hline Yunanistan & 40.0 & 47.1 & 44.6 & 46.7 & 44.2 & 43.7 & 52.6 & 55.5 & 48.4 & 44.9 & 49.4 & 47.3 & 48.1 & 70.0 & 87.2 & 71.9 \\
\hline Suriye & 50.8 & 39.7 & 54.8 & 35.4 & 53.4 & 63.0 & 75.0 & 48.3 & 56.9 & 58.1 & 62.2 & 82.3 & 62.4 & 54.2 & 61.9 & 69.2 \\
\hline Dünya & 1823.3 & 1676.6 & 1721.4 & 1703.0 & 1851.4 & 1864.0 & 1956.9 & 1845.9 & 2191.4 & 2068.0 & 2106.8 & 2145.1 & 2223.9 & 2245.8 & 2253.9 & 2318.0 \\
\hline
\end{tabular}

Söz konusu ülkeler 2001-2016 döneminde dünya kiraz üretiminin ortalama \%81'ini üretmişlerdir (Şekil 2.). Türkiye özellikle son on yıldır lider pozisyonda olup dünya kiraz üretiminin \%19’unu üretmiştir. 


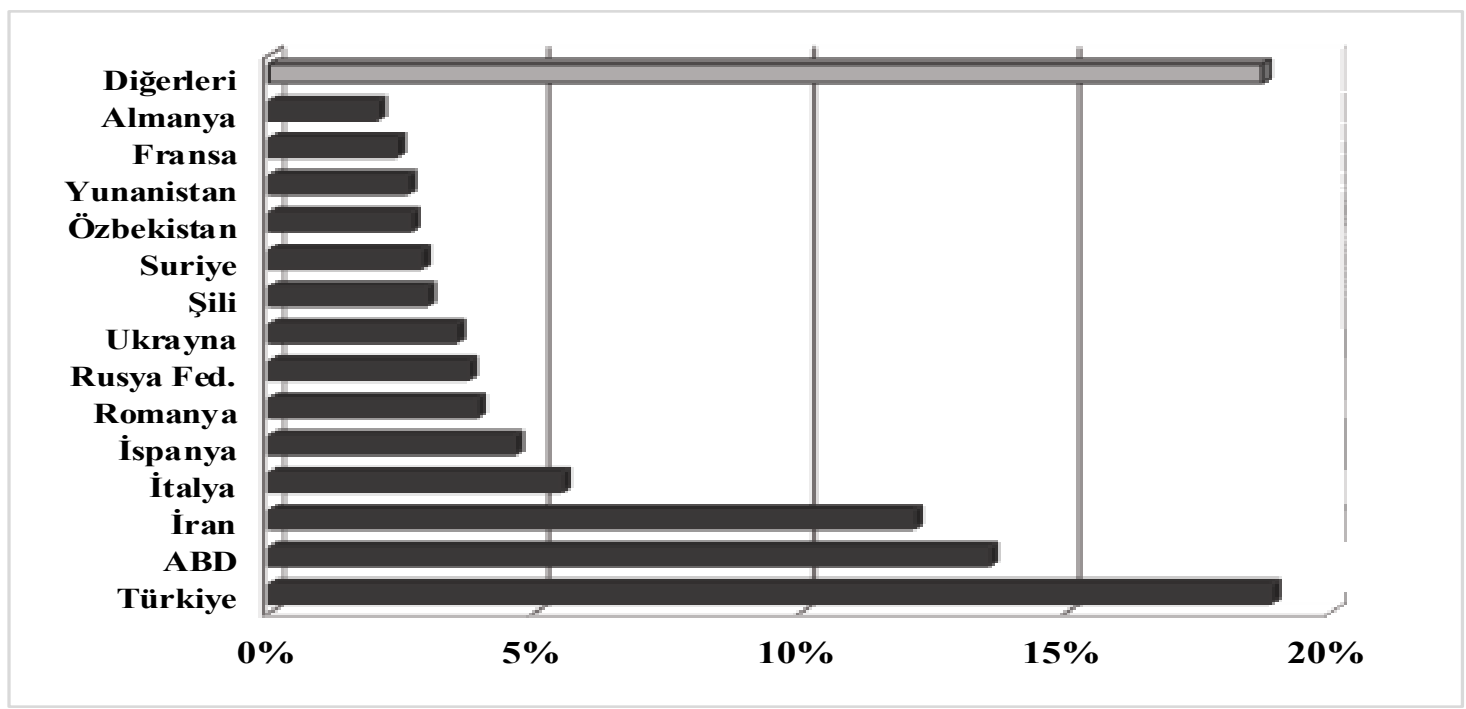

Şekil 2. Önemli kiraz üreticisi ülkelerin 2001-2016 dönemi pay1 (\%).

\subsection{Dünya kiraz ticareti}

2001-2017 yılları arasında, dünya kiraz ithalat miktarı 194418 tondan 540782 tona yükselmiş, ithalat değeri ise yedi kat artmıştır (Çizelge 2.).

Çizelge 2. Dünya kiraz ticareti değişimi

\begin{tabular}{ccccccc}
\hline Yıllar & $\begin{array}{c}\text { İthalat } \\
\text { Miktarı } \\
\text { (ton) }\end{array}$ & $\begin{array}{c}\text { İthalat Değeri } \\
\text { (bin \$) }\end{array}$ & $\begin{array}{c}\text { İthalat Birim } \\
\text { Değeri } \\
\text { (\$/kg) }\end{array}$ & $\begin{array}{c}\text { İhracat } \\
\text { Miktarı } \\
\text { (ton) }\end{array}$ & $\begin{array}{c}\text { İhracat Değeri } \\
\text { (bin \$) }\end{array}$ & $\begin{array}{c}\text { İhracat Birim } \\
\text { Değeri } \\
\text { (\$/kg) }\end{array}$ \\
\hline $\mathbf{2 0 0 1}$ & 194.418 & 362.842 & 2.18 & 218.720 & 401.665 & 1.84 \\
$\mathbf{2 0 0 2}$ & 186.582 & 448.479 & 2.40 & 206.257 & 433.331 & 2.10 \\
$\mathbf{2 0 0 3}$ & 225.620 & 552.818 & 2.45 & 223.512 & 546.783 & 2.45 \\
$\mathbf{2 0 0 4}$ & 237.680 & 630.634 & 2.65 & 242.581 & 590.127 & 2.43 \\
$\mathbf{2 0 0 5}$ & 238.378 & 673.419 & 2.83 & 237.254 & 646.262 & 2.72 \\
$\mathbf{2 0 0 6}$ & 296.210 & 811.448 & 2.74 & 270.162 & 768.531 & 2.85 \\
$\mathbf{2 0 0 7}$ & 286.324 & 913.021 & 3.19 & 250.015 & 859.942 & 3.44 \\
$\mathbf{2 0 0 8}$ & 311.701 & 1066.457 & 3.42 & 256.713 & 1048.339 & 4.08 \\
$\mathbf{2 0 0 9}$ & 334.900 & 1013.640 & 3.03 & 299.718 & 962.752 & 3.21 \\
$\mathbf{2 0 1 0}$ & 343.585 & 1216.986 & 3.54 & 344.832 & 1201.743 & 3.49 \\
$\mathbf{2 0 1 1}$ & 408.742 & 1575.993 & 3.86 & 411.404 & 1570.436 & 3.82 \\
$\mathbf{2 0 1 2}$ & 370.338 & 1651.959 & 4.56 & 384.539 & 1651.057 & 4.29 \\
$\mathbf{2 0 1 3}$ & 359.291 & 1568.297 & 4.37 & 363.549 & 1590.344 & 4.37 \\
$\mathbf{2 0 1 4}$ & 431.988 & 2053.317 & 4.75 & 429.705 & 1876.345 & 4.37 \\
$\mathbf{2 0 1 5}$ & 506.231 & 2076.711 & 4.10 & 480.506 & 1771.684 & 3.69 \\
$\mathbf{2 0 1 6}$ & 564.684 & 2555.513 & 4.53 & 570.251 & 2390.276 & 4.19 \\
$\mathbf{2 0 1 7}$ & 540.782 & 2523.109 & 4.67 & 519.673 & 2194.388 & 4.22 \\
\hline Kaynak: TRADE MAP, 2018. & & & & &
\end{tabular}

Dünya kiraz ithalatında ilk onda yer alan ülkelerin durumu "Çizelge 3." te gösterilmiştir. 2001-2017 döneminde miktar olarak toplamda ilk on ülke, dünya kiraz ithalatının ortalama \%71'ini gerçekleştirmiştir. Dünya ithalat oranından aldıkları pay, en düşük \%63 (\%62.7) ile 2001 yılında; en yüksek ise \%82 ile 2011 yılında olmuştur. Söz konusu dönemde toplamda en yüksek ithalatı 880710 ton ile Rusya gerçekleştirmiştir ve dünya ithalatındaki payı \%15'tir. Almanya, Çin, Hong Kong ve Kanada ise \%13.5 ile \%6.8 arasındaki ithalat payları ile Rusya'yı takip etmektedir. Çin ve Hong Kong, 2001 yılında dünya kiraz ithalatının sadece \%3'ünü gerçekleştirirken 2017 y1lına gelindiğinde bu oran \%34'e yükselmiştir. Benzer şekilde Rusya'nın payı da \%2'den \%11'e yükselmiştir. Almanya'nın payı ise $\% 30$ 'dan $\% 9$ 'a düşmüştür. 
Çizelge 3. İlk on ithalatçı ülke ve ithalat miktarı durumu (ton)

\begin{tabular}{|c|c|c|c|c|c|c|c|c|c|c|c|c|}
\hline Yillar & $\begin{array}{c}\text { Rusya } \\
\text { Fed. }\end{array}$ & Almanya & Çin & $\begin{array}{l}\text { Hong } \\
\text { Kong }\end{array}$ & Kanada & $\begin{array}{c}\text { Birl. } \\
\text { Krallık }\end{array}$ & ABD & Hollanda & Avusturya & Fransa & $\begin{array}{c}10 \text { Ülke } \\
\text { Itthalat } \\
\text { Toplamı } \\
\text { (ton) }\end{array}$ & $\begin{array}{c}\text { Dünya } \\
\text { içindeki } \\
\text { payı } \\
(\%)\end{array}$ \\
\hline 2001 & 4.254 & 57.965 & 378 & 5.266 & 10.058 & 13.315 & 5.816 & 11.149 & 8.144 & 5.475 & 121.820 & 63 \\
\hline 2002 & 4.123 & 50.292 & 602 & 5.956 & 9.165 & 15.725 & 10.718 & 11.112 & 4.900 & 5.801 & 118.394 & 63 \\
\hline 2003 & 17.038 & 49.971 & 1.448 & 7.264 & 15.274 & 16.901 & 7.067 & 14.291 & 8.326 & 6.070 & 143.650 & 64 \\
\hline 2004 & 31.598 & 50.183 & 707 & 5.452 & 12.309 & 16.337 & 6.604 & 13.896 & 6.411 & 6.514 & 150.011 & 63 \\
\hline 2005 & 34.913 & 48.672 & 286 & 5.034 & 17.993 & 19.820 & 11.250 & 14.236 & 4.085 & 5.581 & 161.870 & 68 \\
\hline 2006 & 51.785 & 57.601 & 188 & 6.631 & 19.816 & 22.522 & 12.753 & 15.390 & 4.426 & 7.051 & 198.163 & 67 \\
\hline 2007 & 62.170 & 41.921 & 611 & 8.081 & 25.524 & 18.257 & 15.469 & 11.900 & 7.569 & 8.922 & 200.424 & 70 \\
\hline 2008 & 59.982 & 49.425 & 3.327 & 11.275 & 24.689 & 16.494 & 24.668 & 18.446 & 3.993 & 5.304 & 217.603 & 70 \\
\hline 2009 & 77.430 & 45.932 & 6.184 & 18.300 & 30.493 & 18.319 & 12.693 & 6.713 & 4.643 & 6.776 & 227.483 & 68 \\
\hline 2010 & 77.816 & 38.919 & 40.657 & 20.542 & 27.286 & 15.802 & 20.195 & 17.876 & 4.173 & 6.509 & 269.775 & 79 \\
\hline 2011 & 80.255 & 58.662 & 67.861 & 31.859 & 32.548 & 18.493 & 20.397 & 9.428 & 3.959 & 10.661 & 334.123 & 82 \\
\hline 2012 & 68.200 & 36.084 & 41.589 & 45.843 & 37.174 & 18.876 & 11.670 & 6.790 & 2.890 & 7.861 & 276.977 & 75 \\
\hline 2013 & 72.914 & 35.458 & 37.539 & 32.041 & 24.677 & 14.679 & 8.526 & 7.032 & 17.617 & 6.817 & 257.300 & 72 \\
\hline 2014 & 56.701 & 34.178 & 65.063 & 58.123 & 29.891 & 18.823 & 11.784 & 7.547 & 15.462 & 7.220 & 304.792 & 71 \\
\hline 2015 & 62.428 & 36.984 & 91.484 & 63.006 & 24.211 & 18.350 & 13.298 & 8.775 & 18.348 & 7.808 & 344.692 & 68 \\
\hline 2016 & 57.517 & 45.134 & 109.255 & 99.496 & 23.583 & 17.019 & 10.679 & 5.904 & 29.243 & 5.977 & 403.807 & 72 \\
\hline 2017 & 61.586 & 51.370 & 101.885 & 80.981 & 32.631 & 16.043 & 11.945 & 9.039 & 19.790 & 6.396 & 391.666 & 72 \\
\hline Toplam & 880710 & 788751 & 569064 & 505150 & 397322 & 295775 & 215532 & 189524 & 163979 & 116743 & 4122550 & 71 \\
\hline $\begin{array}{l}\text { Payı } \\
\text { (\%) }\end{array}$ & 15.1 & 13.5 & 9.7 & 8.7 & 6.8 & 5.1 & 3.7 & 3.2 & 2.8 & 2.0 & 71 & \\
\hline
\end{tabular}

Dünyada kiraz ihracatında büyük bir rekabet bulunmaktadır. Söz konusu rekabet, ilk onda yer alan; Şili, ABD, Hong Kong, Türkiye, İspanya, Avusturya, Özbekistan, Yeni Zelanda, Kanada ve İtalya arasında yaşanmaktadır. Şili en büyük kiraz ihracatçısı ülke konumuyla ilk sırada, ABD ise ikinci sırada bulunmaktadır. Türkiye ise genellikle üçüncü sırada yer almakla birlikte 2015 y1lından bu yana Hong Kong üçüncü sıraya yerleşmeye başlamıştır (Çizelge 4.).

Çizelge 4. İlk dört ihracatçı ülke ve ihracat değeri durumu (Bin \$)

\begin{tabular}{rrrrr}
\hline Yıllar & \multicolumn{1}{c}{ Şili } & ABD & \multicolumn{1}{c}{ Türkiye } & \multicolumn{1}{l}{ Hong Kong } \\
\hline $\mathbf{2 0 0 1}$ & 21.674 & 152.093 & 48.702 & 15.521 \\
$\mathbf{2 0 0 2}$ & 38.200 & 142.548 & 49.276 & 20.028 \\
$\mathbf{2 0 0 3}$ & 36.188 & 171.615 & 76.944 & 28.989 \\
$\mathbf{2 0 0 4}$ & 31.934 & 178.191 & 117.987 & 32.650 \\
$\mathbf{2 0 0 5}$ & 56.044 & 217.871 & 92.146 & 39.127 \\
$\mathbf{2 0 0 6}$ & 74.307 & 205.927 & 101.981 & 64.461 \\
$\mathbf{2 0 0 7}$ & 107.516 & 274.817 & 106.666 & 30.223 \\
$\mathbf{2 0 0 8}$ & 144.750 & 298.898 & 113.445 & 46.692 \\
$\mathbf{2 0 0 9}$ & 149.172 & 309.429 & 132.579 & 80.040 \\
$\mathbf{2 0 1 0}$ & 300.782 & 356.467 & 147.828 & 33.806 \\
$\mathbf{2 0 1 1}$ & 368.615 & 449.223 & 131.001 & 73.845 \\
$\mathbf{2 0 1 2}$ & 374.196 & 524.065 & 156.394 & 98.855 \\
$\mathbf{2 0 1 3}$ & 391.334 & 427.604 & 154.717 & 78.424 \\
$\mathbf{2 0 1 4}$ & 593.501 & 475.011 & 145.032 & 127.816 \\
$\mathbf{2 0 1 5}$ & 516.761 & 427.294 & 122.672 & 181.812 \\
$\mathbf{2 0 1 6}$ & 850.729 & 455.120 & 182.535 & 347.643 \\
$\mathbf{2 0 1 7}$ & 513.182 & 603.000 & 159.042 & 301.736 \\
\hline
\end{tabular}

Kaynak: TRADE MAP, 2018.

Mevsimler ve aylar açısından kiraz ihracatı incelenecek olursa; "Çizelge 5." te görüldüğ̈̈ gibi, toplam ihracatın \%69'u mayıs, haziran, temmuz ve ağustos aylarında; \%29'luk bölümü ise kasım, 
aralık, ocak ve şubat aylarında gerçekleştirilmektedir. Türkiye'de kiraz ihracatının tamamı mayısağustos arası dönemde yapılmaktadır. 2017 yılında ihracatın; \%52.6's1 Haziran ayında, \%35.3'üTemmuz, \%12'si ise Mayıs ayında gerçekleştirilmiştir.

Çizelge 5. 2017 yılı ilk on ihracatçı ülke ve aylara göre ihracat oranları (\%)

\begin{tabular}{|c|c|c|c|c|c|c|c|c|c|c|c|c|c|c|}
\hline $\begin{array}{l}\text { İhracatçı } \\
\text { Ülkeler }\end{array}$ & $\begin{array}{l}5 . \\
\text { AY } \\
\%\end{array}$ & $\begin{array}{l}\mathbf{6 .} \\
\mathbf{A Y} \\
\%\end{array}$ & $\begin{array}{c}7 . \\
\text { AY } \\
\%\end{array}$ & $\begin{array}{l}8 . \\
\text { AY } \\
\%\end{array}$ & $\begin{array}{c}9 . \\
\text { AY } \\
\%\end{array}$ & $\begin{array}{l}10 . \\
\text { AY } \\
\%\end{array}$ & $\begin{array}{l}11 . \\
\text { AY } \\
\%\end{array}$ & $\begin{array}{l}12 . \\
\text { AY } \\
\%\end{array}$ & $\begin{array}{c}1 . \\
\text { AY } \\
\%\end{array}$ & $\begin{array}{c}2 . \\
\text { AY } \\
\%\end{array}$ & $\begin{array}{c}\text { 3. } \\
\text { AY } \\
\%\end{array}$ & $\begin{array}{l}4 . \\
\text { AY } \\
\%\end{array}$ & $\begin{array}{c}\text { 5.+6.+7. } \\
+8 . \mathrm{AY} \\
\%\end{array}$ & $\begin{array}{c}11 .+12 .+1 . \\
+2 . \mathrm{AY} \\
\%\end{array}$ \\
\hline ABD & 20.2 & 25.7 & 39.5 & 11.0 & 0.1 & 0.0 & 0.0 & 0.3 & 0.2 & 0.1 & 2.2 & 0.7 & 96.4 & 0.67 \\
\hline Şili & 0.0 & 0.0 & 0.0 & 0.0 & 0.0 & 0.0 & 3.9 & 49.6 & 43.7 & 2.5 & 0.3 & 0.0 & 0.0 & 99.7 \\
\hline Hong Kong & 2.9 & 10.3 & 29.3 & 24.1 & 1.1 & 0.2 & 1.7 & 10.8 & 16.5 & 3.0 & 0.1 & 0.0 & 66.6 & 32.0 \\
\hline Türkiye & 12.0 & 52.6 & 35.3 & 0.1 & 0.0 & 0.0 & 0.0 & 0.0 & 0.0 & 0.0 & 0.0 & 0.0 & 100.0 & 0.0 \\
\hline İspanya & 28.8 & 49.3 & 15.9 & 1.5 & 0.7 & 0.1 & 0.2 & 1.8 & 0.3 & 0.2 & 0.0 & 1.4 & 95.5 & 2.5 \\
\hline Avusturya & 5.6 & 46.7 & 47.5 & 0.2 & 0.0 & 0.0 & 0.0 & 0.0 & 0.0 & 0.0 & 0.0 & 0.0 & 100.0 & 0.0 \\
\hline Özbekistan & 33.4 & 64.9 & 1.7 & 0.0 & 0.0 & 0.0 & 0.0 & 0.0 & 0.0 & 0.0 & 0.0 & 0.0 & 100.0 & 0.0 \\
\hline Y. Zelanda & 0.0 & 0.0 & 0.0 & 0.0 & 0.0 & 0.0 & 0.1 & 26.7 & 67.3 & 5.9 & 0.0 & 0.0 & 0.0 & 100.0 \\
\hline Kanada & 0.0 & 0.7 & 19.9 & 73.0 & 5.9 & 0.0 & 0.1 & 0.2 & 0.1 & 0.0 & 0.1 & 0.0 & 99.5 & 0.50 \\
\hline İtalya & 31.4 & 59.8 & 7.2 & 1.1 & 0.2 & 0.0 & 0.0 & 0.1 & 0.0 & 0.0 & 0.0 & 0.2 & 99.5 & 0.16 \\
\hline
\end{tabular}

Kaynak: TRADE MAP, 2018 verilerine dayanarak hesaplanmıştır.

Kuzey ve güney yarı kürede bulunan ülkeler üretim dönemlerinin farklı olmasından dolayı farklı aylarda ihracat yapmaktadırlar. Bununla beraber ABD ve Hong Kong neredeyse yılın tüm aylarında ihracat yapmaktadır. Hong Kong'un kiraz üretimi bulunmamakla birlikte son üç yıldır ihracat değeri olarak üçüncü sırada yer almaktadır (Çizelge 4.). Reexport yapan Hong Kong, 2017 yılında yaklaşık 445 milyon dolarlık kiraz ithal etmiş ve 301 milyon dolarlık ihracat gerçekleştirmiştir. Bunun 300 milyon dolarlık kısmını sadece Çin'e satmıştır.

\subsection{Türkiye kiraz üretimi ve dış ticareti}

Türkiye kiraz üretiminin son 17 y1llık üretimi incelendiğinde; üretim miktarı yaklaşık üç kat artarak 250 bin tondan 627 bin tona ulaşmıştır (Şekil 3.).

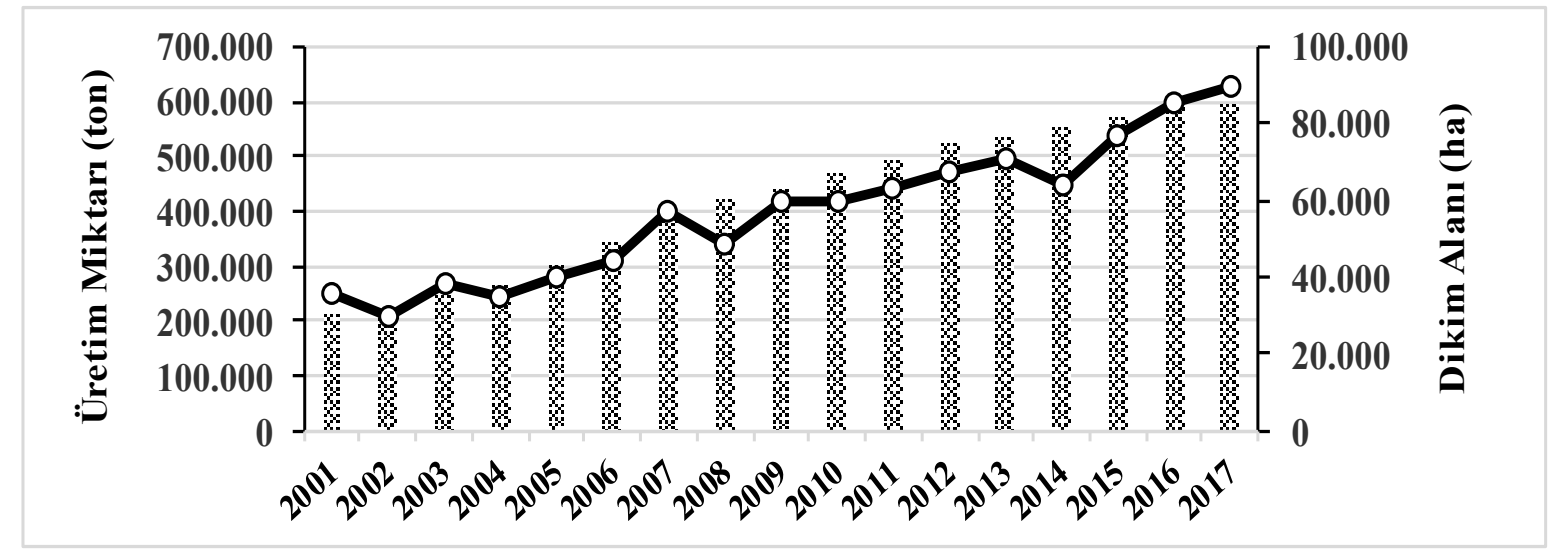

Şekil 3. Yıllar itibariyle Türkiye kiraz üretim ve dikim alanı durumu.

Söz konusu dönem için Türkiye kiraz verimi dünya verim ortalamasının üzerinde gerçekleşmiştir. Türkiye'de kiraz veriminin düşük olduğu yıllarda ihracat gerilemiş, ithalat ise bu yıllarda yapılmıştır. Türkiye'de kiraz üretimi miktar olarak önemli olmasına rağmen ihracat oranı üretime göre düşük kalmaktadır. "Şekil 4.” te izlendiği gibi, 2001-2017 y1lları arasında Türkiye'nin kiraz ihracatında büyük bir dalgalanma olduğu görülmektedir. Kiraz ihracat değeri, en yüksek 182.5 milyon dolar ile 2016 yılında gerçekleşmiştir. 2017 yılında ise 159 milyon dolara gerilemiştir. Türkiye kiraz ithalatı ise yok denecek kadar azdır. En yüksek ithalat 2008 yılında gerçekleşmiştir. 


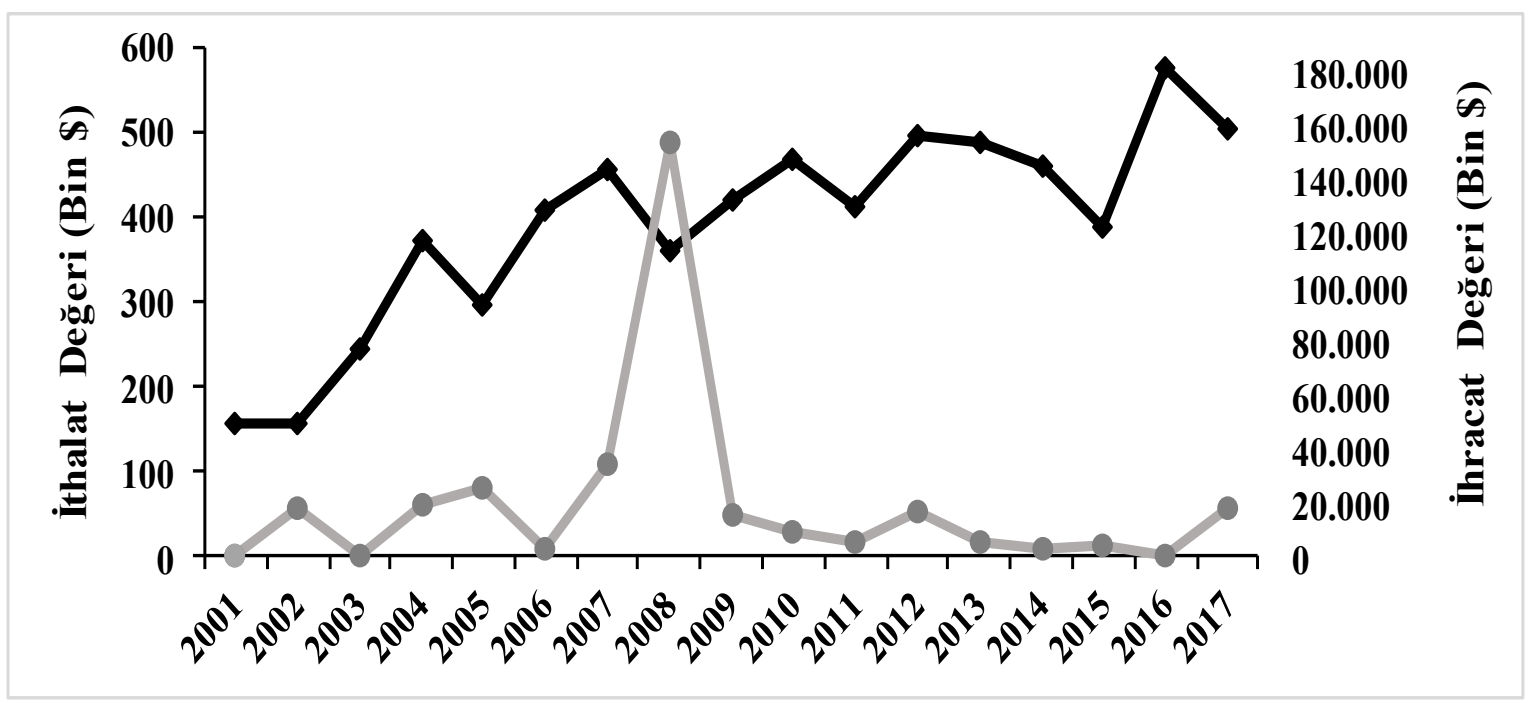

Şekil 4. 2001-2017 dönemi Türkiye kiraz diş ticareti durumu (TRADE MAP, 2018).

Türkiye'nin kiraz ihracatı 2001-2017 döneminde ortalama olarak 124 milyon dolar civarındadır. İhracat yapılan ülkelerin aldığı paylar incelendiğinde ise; AB ülkelerinin önemli bir pazar olduğu görülmektedir. Bununla birlikte son 10 yıldır Rusya Federasyonu da Türkiye için önemli bir pazar haline gelmiştir. Belirtilen dönem için yaklaşık 50 milyon dolarlık ortalama ihracat değeri ile Almanya ilk sırada yer almaktadır ve oran olarak aldığı pay \%39'dur (Şekil 5.). Bu ülkeyi 14 milyon dolarla İngiltere ve 11 milyon dolarla Rusya Federasyonu izlemektedir. Diğer on iki ülkeye yapılan ihracat ise 10 milyon doların altında gerçekleşmiştir.

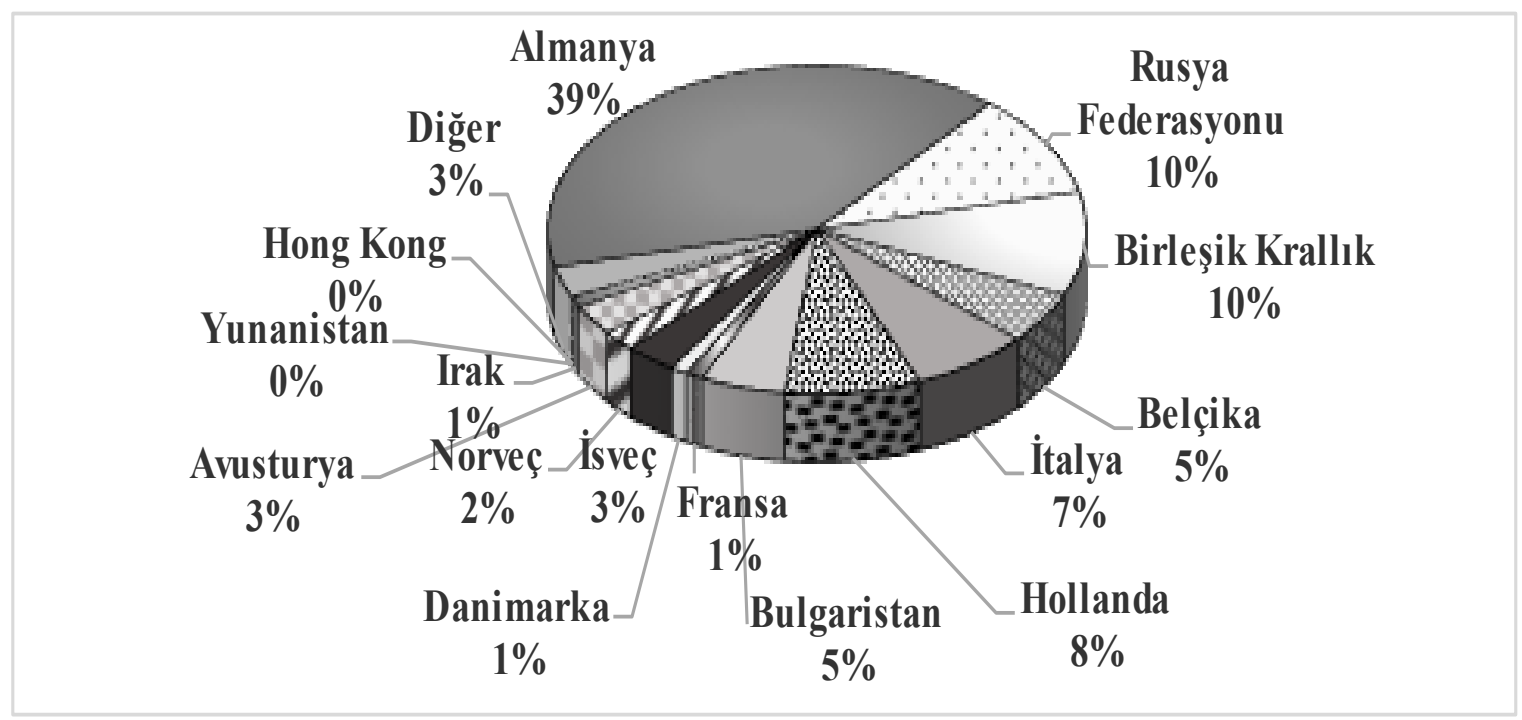

Şekil 5. 2001-2017 dönemi Türkiye ortalama kiraz ihracat değerinin ülkelere göre dağılımı (\%).

\subsection{Türkiye'nin rekabet gücü analizi}

Türkiye'nin ve kiraz ihracatında rakip olan ülkelerin 2001-2017 yılları arasında karşılaştırmalı üstünlük endeks değerleri "Çizelge 6." da yer almaktadır. Türkiye'nin RCA endeks değeri, 2017 yılında, 2001 yılına göre \%66 azalmıştır. Benzer şekilde ABD’nin \%6; İspanya'nın \%43 ve İtalya'nın ise \%18 azalırken, Avusturya, Özbekistan ve Kanada'nın sirasıyla \%66; \%230 ve \%1457 oranında artış gerçekleşmiştir. 
Çizelge 6. Balassa'nın açıklanmış karşılaştırmalı üstünlük endeksi (RCA)

\begin{tabular}{cccccccc}
\hline Yllar & Türkiye & ABD & İspanya & Avusturya & Özbekistan & Kanada & İtalya \\
\hline $\mathbf{2 0 0 1}$ & 23.99 & 3.40 & 3.42 & 2.01 & 19.03 & 0.07 & 0.99 \\
$\mathbf{2 0 0 2}$ & 20.47 & 3.23 & 4.21 & 1.33 & 6.40 & 0.24 & 0.88 \\
$\mathbf{2 0 0 3}$ & 22.51 & 3.49 & 3.22 & 0.44 & 8.08 & 0.41 & 1.11 \\
$\mathbf{2 0 0 4}$ & 28.83 & 3.60 & 3.06 & 0.18 & 4.19 & 0.56 & 0.45 \\
$\mathbf{2 0 0 5}$ & 20.38 & 3.93 & 3.99 & 0.21 & 68.50 & 0.52 & 1.57 \\
$\mathbf{2 0 0 6}$ & 23.51 & 3.25 & 5.48 & 0.29 & 28.71 & 0.68 & 0.97 \\
$\mathbf{2 0 0 7}$ & 21.62 & 3.80 & 2.51 & 0.45 & 52.42 & 0.76 & 1.21 \\
$\mathbf{2 0 0 8}$ & 13.10 & 3.50 & 2.91 & 0.16 & 0.60 & 0.51 & 1.61 \\
$\mathbf{2 0 0 9}$ & 16.69 & 3.76 & 4.82 & 0.15 & 21.90 & 1.00 & 0.68 \\
$\mathbf{2 0 1 0}$ & 16.30 & 3.51 & 3.47 & 0.95 & 46.37 & 0.96 & 0.65 \\
$\mathbf{2 0 1 1}$ & 11.18 & 3.51 & 3.19 & 0.96 & 61.32 & 1.09 & 0.98 \\
$\mathbf{2 0 1 2}$ & 11.42 & 3.98 & 2.96 & 1.56 & 18.19 & 1.11 & 1.11 \\
$\mathbf{2 0 1 3}$ & 12.17 & 3.21 & 2.53 & 4.73 & 58.12 & 1.04 & 1.14 \\
$\mathbf{2 0 1 4}$ & 9.31 & 2.95 & 2.93 & 3.26 & 60.95 & 0.99 & 0.47 \\
$\mathbf{2 0 1 5}$ & 7.94 & 2.64 & 2.12 & 3.36 & 22.82 & 1.43 & 0.61 \\
$\mathbf{2 0 1 6}$ & 8.58 & 2.10 & 1.58 & 4.29 & 45.50 & 1.02 & 0.33 \\
$\mathbf{2 0 1 7}$ & 8.04 & 3.20 & 1.95 & 3.33 & 62.75 & 1.09 & 0.81 \\
\hline Ortalama & $\mathbf{1 6 . 2 4}$ & $\mathbf{3 . 3 6}$ & $\mathbf{3 . 2 0}$ & $\mathbf{1 . 6 3}$ & $\mathbf{3 4 . 4 6}$ & $\mathbf{0 . 7 9}$ & $\mathbf{0 . 9 2}$ \\
\hline
\end{tabular}

Kaynak: TRADE MAP, 2018 verilerine dayanarak hesaplanmıştır.

Türkiye ve diğer ülkeler için hesaplanan Balassa ve Vollrath'ın RCA ve RXA endeks değerleri birbiriyle benzerlik göstermektedir (Çizelge 7.).

Çizelge 7. Vollrath'ın göreli ihracat avantaj1 endeksi (RXA)

\begin{tabular}{cccccccc}
\hline Yıllar & Türkiye & ABD & İspanya & Avusturya & Özbekistan & Kanada & İtalya \\
\hline $\mathbf{2 0 0 1}$ & 27.21 & 5.03 & 3.26 & 2.04 & 19.16 & 0.07 & 0.99 \\
$\mathbf{2 0 0 2}$ & 22.98 & 4.43 & 4.09 & 1.34 & 6.42 & 0.23 & 0.88 \\
$\mathbf{2 0 0 3}$ & 26.08 & 4.76 & 3.21 & 0.44 & 8.10 & 0.40 & 1.12 \\
$\mathbf{2 0 0 4}$ & 35.78 & 4.84 & 2.91 & 0.18 & 4.20 & 0.55 & 0.44 \\
$\mathbf{2 0 0 5}$ & 23.66 & 5.46 & 3.87 & 0.21 & 70.31 & 0.51 & 1.60 \\
$\mathbf{2 0 0 6}$ & 28.06 & 4.13 & 5.25 & 0.29 & 29.09 & 0.67 & 0.96 \\
$\mathbf{2 0 0 7}$ & 25.78 & 5.12 & 2.38 & 0.44 & 53.74 & 0.75 & 1.22 \\
$\mathbf{2 0 0 8}$ & 14.57 & 4.50 & 2.89 & 0.16 & 0.60 & 0.51 & 1.64 \\
$\mathbf{2 0 0 9}$ & 19.21 & 5.06 & 4.63 & 0.15 & 22.12 & 1.00 & 0.67 \\
$\mathbf{2 0 1 0}$ & 18.45 & 4.57 & 3.44 & 0.95 & 47.32 & 0.96 & 0.65 \\
$\mathbf{2 0 1 1}$ & 12.11 & 4.53 & 3.16 & 0.96 & 62.78 & 1.09 & 0.98 \\
$\mathbf{2 0 1 2}$ & 12.51 & 5.48 & 2.94 & 1.57 & 18.30 & 1.11 & 1.11 \\
$\mathbf{2 0 1 3}$ & 13.37 & 4.02 & 2.54 & 4.90 & 59.67 & 1.04 & 1.14 \\
$\mathbf{2 0 1 4}$ & 10.00 & 3.61 & 2.64 & 3.33 & 62.37 & 0.99 & 0.46 \\
$\mathbf{2 0 1 5}$ & 8.46 & 3.16 & 1.80 & 3.43 & 23.01 & 1.45 & 0.61 \\
$\mathbf{2 0 1 6}$ & 9.21 & 2.36 & 1.49 & 4.43 & 46.48 & 1.02 & 0.32 \\
$\mathbf{2 0 1 7}$ & 8.59 & 4.07 & 1.69 & 3.41 & 64.68 & 1.09 & 0.81 \\
\hline Ortalama & $\mathbf{1 8 . 5 9}$ & $\mathbf{4 . 4 2}$ & $\mathbf{3 . 0 7}$ & $\mathbf{1 . 6 6}$ & $\mathbf{3 5 . 2 0}$ & $\mathbf{0 . 7 9}$ & $\mathbf{0 . 9 2}$ \\
\hline
\end{tabular}

Kaynak: TRADE MAP, 2018 verilerine dayanarak hesaplanmıştır.

Türkiye'nin kiraz ihracatında küresel piyasalarda büyük bir karşılaştırmalı üstünlüğü bulunmaktadır. Bununla beraber, son yıllarda bu üstünlüğün göreli olarak azalmakta olduğu göze çarpmaktadır. Bu tespitler, kiraz sektörünün karşılaştırmalı üstünlüğünün analiz edildiği Bitkisel Üretim Özel İhtisas Komisyonu Raporu (Anonim, 2014) ile Saçtı ve Dellal (2018) tarafından yapılan araştırma sonuçlarıyla örtüşmektedir. Göreli İthalat Nüfuz (RMP) endeks değeri 1'den küçük ise rekabetçi avantaj mevcuttur. 2001 ile 2017 yılları arasında hesaplanan RMP endeksine göre; Türkiye'nin endeks değeri çok düşük çıkmıştır. Bunun nedeni kiraz ithalatının toplam ithalat 
içerisinde çok düşük bir paya sahip olmasıdır. Kiraz sektörü Kanada ve Avusturya için dezavantajlı, başta Türkiye olmak üzere sırasıyla Özbekistan, ABD, İspanya ve İtalya için ise avantajlı bir durumdadır (Çizelge 8.).

Çizelge 8. Vollrath'ın göreli ithalat avantaj1 endeksi (RMP)

\begin{tabular}{cccccccc}
\hline Yıllar & Türkiye & ABD & İspanya & Avusturya & Özbekistan & Kanada & İtalya \\
\hline $\mathbf{2 0 0 1}$ & 0.0000 & 0.18 & 0.21 & 3.54 & 0.0007 & 1.60 & 1.16 \\
$\mathbf{2 0 0 2}$ & 0.0169 & 0.34 & 0.19 & 2.39 & 0.0008 & 1.64 & 0.78 \\
$\mathbf{2 0 0 3}$ & 0.0000 & 0.02 & 0.29 & 1.78 & 0.0006 & 2.39 & 0.10 \\
$\mathbf{2 0 0 4}$ & 0.0095 & 0.22 & 0.44 & 1.44 & 0.0005 & 2.52 & 1.69 \\
$\mathbf{2 0 0 5}$ & 0.0111 & 0.35 & 0.42 & 1.43 & 0.0096 & 3.14 & 0.97 \\
$\mathbf{2 0 0 6}$ & 0.0011 & 0.43 & 0.49 & 1.28 & 0.0004 & 3.55 & 1.05 \\
$\mathbf{2 0 0 7}$ & 0.0100 & 0.50 & 0.49 & 1.60 & 0.0002 & 4.41 & 0.81 \\
$\mathbf{2 0 0 8}$ & 0.0370 & 0.72 & 0.56 & 1.00 & 0.0002 & 4.64 & 0.77 \\
$\mathbf{2 0 0 9}$ & 0.0043 & 0.04 & 0.55 & 1.04 & 0.0002 & 4.22 & 1.08 \\
$\mathbf{2 0 1 0}$ & 0.0021 & 0.53 & 0.57 & 0.11 & 0.0002 & 4.21 & 0.80 \\
$\mathbf{2 0 1 1}$ & 0.0008 & 0.42 & 0.05 & 0.75 & 0.0001 & 4.14 & 0.65 \\
$\mathbf{2 0 1 2}$ & 0.0026 & 0.24 & 0.32 & 1.02 & 0.0001 & 0.04 & 0.77 \\
$\mathbf{2 0 1 3}$ & 0.0009 & 0.24 & 0.23 & 5.30 & 0.0001 & 3.62 & 0.61 \\
$\mathbf{2 0 1 4}$ & 0.0003 & 0.27 & 0.20 & 3.35 & 0.0001 & 2.62 & 0.55 \\
$\mathbf{2 0 1 5}$ & 0.0005 & 0.24 & 0.19 & 0.33 & 0.0001 & 2.12 & 0.39 \\
$\mathbf{2 0 1 6}$ & 0.0001 & 0.19 & 0.13 & 4.80 & 0.0001 & 1.71 & 0.52 \\
$\mathbf{2 0 1 7}$ & 0.0018 & 0.22 & 0.17 & 3.13 & 0.0074 & 2.27 & 0.29 \\
\hline Ortalama & $\mathbf{0 . 0 0 6}$ & $\mathbf{0 . 3 0}$ & $\mathbf{0 . 3 2}$ & $\mathbf{2 . 0 2}$ & $\mathbf{0 . 0 0}$ & $\mathbf{2 . 8 7}$ & $\mathbf{0 . 7 6}$ \\
\hline Kay
\end{tabular}

Kaynak: TRADE MAP, 2018 verilerine dayanarak hesaplanmıştır.

Diğer bir rekabet endeksi olan göreli ticaret avantaj1 endeksi (RTA) ihracat ve ithalat avantajlarının önemi ile ağırlıklandırılan bir göstergedir ve pozitif bir değer rekabetçi avantaja, negatif bir değer ise dezavantaja karşı1ık gelmektedir. 2001-2017 döneminde RTA endeksi ülkeler açısından incelendiğinde; Türkiye, ABD, İspanya ve Özbekistan'ın rekabetçi avantaja sahip olduğu, Avusturya, Kanada ve İtalya'nın ise karşılaştırmalı dezavantaja sahip olduğu görülmektedir (Çizelge 9.). Bununla beraber Türkiye, ABD ve İspanya'nın bu avantajlı konumunu giderek kaybettiği, Özbekistan'ın ise avantajını artırdığı söylenebilir. 
Çizelge 9. Vollrath'ın göreli ticaret avantaji endeksi (RTA)

\begin{tabular}{cccccccc}
\hline Yıllar & Türkiye & ABD & İspanya & Avusturya & Özbekistan & Kanada & İtalya \\
\hline $\mathbf{2 0 0 1}$ & 27.21 & 4.86 & 3.05 & -1.50 & 19.16 & -1.53 & -0.17 \\
$\mathbf{2 0 0 2}$ & 22.96 & 4.09 & 3.91 & -1.06 & 6.41 & -1.40 & 0.10 \\
$\mathbf{2 0 0 3}$ & 26.08 & 4.74 & 2.92 & -1.34 & 8.10 & -1.99 & 1.01 \\
$\mathbf{2 0 0 4}$ & 35.77 & 4.61 & 2.47 & -1.25 & 4.20 & -1.98 & -1.25 \\
$\mathbf{2 0 0 5}$ & 23.65 & 5.11 & 3.45 & -1.22 & 70.30 & -2.63 & 0.63 \\
$\mathbf{2 0 0 6}$ & 28.06 & 3.70 & 4.76 & -1.00 & 29.09 & -2.88 & -0.08 \\
$\mathbf{2 0 0 7}$ & 25.77 & 4.61 & 1.89 & -1.16 & 53.74 & -3.65 & 0.40 \\
$\mathbf{2 0 0 8}$ & 14.53 & 3.78 & 2.33 & -0.85 & 0.60 & -4.13 & 0.87 \\
$\mathbf{2 0 0 9}$ & 19.20 & 5.02 & 4.08 & -0.89 & 22.12 & -3.22 & -0.40 \\
$\mathbf{2 0 1 0}$ & 18.45 & 4.04 & 2.87 & 0.84 & 47.32 & -3.25 & -0.16 \\
$\mathbf{2 0 1 1}$ & 12.11 & 4.11 & 3.11 & 0.20 & 62.78 & -3.04 & 0.33 \\
$\mathbf{2 0 1 2}$ & 12.51 & 5.24 & 2.62 & 0.54 & 18.30 & 1.07 & 0.35 \\
$\mathbf{2 0 1 3}$ & 13.37 & 3.78 & 2.31 & -0.40 & 59.67 & -2.58 & 0.53 \\
$\mathbf{2 0 1 4}$ & 10.00 & 3.35 & 2.44 & -0.02 & 62.37 & -1.63 & -0.09 \\
$\mathbf{2 0 1 5}$ & 8.46 & 2.92 & 1.61 & 3.11 & 23.01 & -0.68 & 0.22 \\
$\mathbf{2 0 1 6}$ & 9.21 & 2.17 & 1.35 & -0.37 & 46.48 & -0.69 & -0.20 \\
$\mathbf{2 0 1 7}$ & 8.59 & 3.84 & 1.51 & 0.28 & 64.68 & -1.18 & 0.52 \\
\hline Ortalama & $\mathbf{1 8 . 5 8}$ & $\mathbf{4 . 1 2}$ & $\mathbf{2 . 7 5}$ & $\mathbf{- 0 . 3 6}$ & $\mathbf{3 5 . 2 0}$ & $\mathbf{- 2 . 0 8}$ & $\mathbf{0 . 1 5}$ \\
\hline
\end{tabular}

Kaynak: TRADE MAP, 2018 verilerine dayanarak hesaplanmıştır.

Üçüncü endeks olan, bir ülke veya malın karşılaştırmalı üstünlüğünü daha iyi yansıttığı ve o nedenle de daha tercih edilebilir olduğu düşünülen göreli rekabet üstünlüğü (RC) endeksi değerleri "Çizelge 10." da görüldüğü gibidir.

Türkiye'nin söz konusu dönemde 2001 ve 2003 yıllarında kiraz ithalatı bulunmamaktadır ve bu yüzden endeks değeri hesaplanamamıștır. Bu iki yıl haricinde Türkiye'nin de ABD, İspanya ve Özbekistan gibi pozitif değerler alması, yine de karşılaştırmalı avantajlara sahip olduğunu göstermektedir. Avusturya, Kanada ve İtalya'nın ise dezavantaja sahip oldukları görülmektedir.

Çizelge 10. Vollrath'1n göreli rekabet üstünlüğü endeksi (RC)

\begin{tabular}{cccccccc}
\hline Yıllar & Türkiye & ABD & İspanya & Avusturya & Özbekistan & Kanada & İtalya \\
\hline $\mathbf{2 0 0 1}$ & - & 3.34 & 2.73 & -0.55 & 10.21 & -3.14 & -0.15 \\
$\mathbf{2 0 0 2}$ & 7.21 & 2.57 & 3.10 & -0.58 & 9.03 & -1.95 & 0.12 \\
$\mathbf{2 0 0 3}$ & - & 5.39 & 2.39 & -1.40 & 9.48 & -1.79 & 2.38 \\
$\mathbf{2 0 0 4}$ & 8.24 & 3.07 & 1.88 & -2.06 & 8.99 & -1.53 & -1.34 \\
$\mathbf{2 0 0 5}$ & 7.67 & 2.73 & 2.22 & -1.93 & 8.90 & -1.82 & 0.50 \\
$\mathbf{2 0 0 6}$ & 10.16 & 2.26 & 2.37 & -1.50 & 11.28 & -1.66 & -0.08 \\
$\mathbf{2 0 0 7}$ & 7.86 & 2.32 & 1.58 & -1.29 & 12.32 & -1.76 & 0.40 \\
$\mathbf{2 0 0 8}$ & 5.97 & 1.83 & 1.64 & -1.86 & 8.20 & -2.22 & 0.76 \\
$\mathbf{2 0 0 9}$ & 8.40 & 4.85 & 2.13 & -1.94 & 11.88 & -1.44 & -0.47 \\
$\mathbf{2 0 1 0}$ & 9.08 & 2.15 & 1.79 & 2.13 & 12.65 & -1.48 & -0.22 \\
$\mathbf{2 0 1 1}$ & 9.66 & 2.37 & 4.16 & 0.24 & 13.18 & -1.33 & 0.41 \\
$\mathbf{2 0 1 2}$ & 8.48 & 3.13 & 2.23 & 0.43 & 12.05 & 3.30 & 0.37 \\
$\mathbf{2 0 1 3}$ & 9.59 & 2.82 & 2.38 & -0.08 & 13.37 & -1.25 & 0.63 \\
$\mathbf{2 0 1 4}$ & 10.40 & 2.61 & 2.56 & -0.01 & 13.74 & -0.97 & -0.18 \\
$\mathbf{2 0 1 5}$ & 9.73 & 2.57 & 2.25 & 2.36 & 12.61 & -0.38 & 0.44 \\
$\mathbf{2 0 1 6}$ & 11.87 & 2.52 & 2.41 & -0.08 & 13.48 & -0.52 & -0.48 \\
$\mathbf{2 0 1 7}$ & 8.48 & 2.89 & 2.28 & 0.09 & 9.08 & -0.73 & 1.04 \\
\hline Ortalama & $\mathbf{8 . 8 5}$ & $\mathbf{2 . 9 1}$ & $\mathbf{2 . 3 6}$ & $\mathbf{- 0 . 4 7}$ & $\mathbf{1 1 . 2 0}$ & $\mathbf{- 1 . 2 2}$ & $\mathbf{0 . 2 4}$ \\
\hline
\end{tabular}

Kaynak: TRADE MAP 2018 verilerine dayanarak hesaplanmıştır. 
RCA, RXA ve RTA değerleri incelendiğinde; endeks değerleri 1'in çok üzerinde bulunmuştur. $\mathrm{Bu}$ değerler, Türkiye'nin uluslararası kiraz ticaretinde rekabet açısından güçlü bir avantaja sahip olduğunu göstermektedir. Bununla birlikte söz konusu dönemde her üç endeks değeri genel olarak gerilemiş̧, en yüksek değeri 2004 yılında almış ve sonrasında düşüşe geçmiştir.

Ülkelerin RC ile RCA değerleri karşılaştırıldığında (bkz. Çizelge 6. ve 10.) RC değerlerinin RCA değerleri kadar yüksek olmadığı görülmektedir. Bu durum, karşılaştırmalı avantaja sahip olan Türkiye, ABD, İspanya ve Özbekistan'ın rekabet üstünlügünün olduğunu, buna karşın rekabet güçlerinin yeterince yüksek olmadığını göstermektedir.

Rekabet gücü, bir ülkenin söz konusu ürün ya da mallarda üretim kapasitesinin ve uzmanlaşmasının düzenli bir şekilde artışını ifade eder. Başka bir deyişle; ihracatta rekabet gücüne sahip olmanın yanı sıra, üstünlük durumunun istikrarlı bir seyir göstermesi de önemli bir durumdur.

"Çizelge 11." incelendiğinde, 2001-2017 döneminde Özbekistan RCA ortalama değeri en yüksek düzeyde olan ülkedir ve rekabet üstünlüğü güçlüdür. Bununla beraber, değişim katsayısı da çok yüksektir. Bu durum, istikrarsızlık düzeyinin de yüksek olduğunu göstermektedir. Onu hem rekabet gücü bakımından hem de yüksek istikrarsızlık durumu ile Türkiye takip etmektedir. Düşük değişim katsayısına sahip ABD ve İspanya'nın ise orta düzeyde rekabet üstünlüğüne sahip olmalarına rağmen istikrarlı bir seyir izledikleri görülmektedir.

Çizelge 11. Karşılaştırmalı üstünlüklere ilişkin istikrar durumu ve rekabet gücü

\begin{tabular}{|c|c|c|c|}
\hline Ülkeler & RCA Ortalama & Değişim Katsayısı (\%) & Rekabet Gücü \\
\hline Türkiye & 16.24 & 251.07 & Yüksek Rekabet Gücü \\
\hline ABD & 3.36 & 6.22 & Orta Rekabet Gücü \\
\hline İspanya & 3.20 & 29.67 & Orta Rekabet Gücü \\
\hline Avusturya & 1.63 & 142.56 & Düşük Rekabet Gücü \\
\hline Özbekistan & 34.46 & 1519.65 & Yüksek Rekabet Gücü \\
\hline Kanada & 0.79 & 15.60 & Rekabet Gücü Yok \\
\hline Ittalya & 0.92 & 13.56 & Rekabet Gücü Yok \\
\hline
\end{tabular}

Kaynak: TRADE MAP, 2018 verilerine dayanarak hesaplanmıştır.

\section{Tartışma ve Sonuç}

Dünyada kiraz ihracatında büyük bir rekabet bulunmaktadır. Türkiye kiraz sektörünün 20012017 yılları arasındaki karşılaştırmalı üstünlük düzeyi ve rekabet gücünün rakip ülkeler ile birlikte incelendiği bu çalışmada elde edilen veriler; Türkiye, Özbekistan, ABD, İspanya ve İtalya arasında rekabet olduğunu ve karşılaştırmalı üstünlüğe sahip olduklarını göstermektedir.

Türkiye'nin kiraz ihracatında küresel piyasalarda büyük bir karşılaştırmalı üstünlüğü bulunmaktadır. Bununla beraber, son yıllarda bu üstünlük göreli olarak azalmaktadır. Bunun en önemli nedenlerinden bazıları; rakiplerin fiyatları ile rekabet edememe, ihracatçıların kaliteli kiraz temininde sorun yaşaması, ülkelerin tarife ve tarife dışı engelleri, vb. olarak sayılabilir. Ayrıca, Türkiye'nin değişen pazar isteklerine uygun niteliklere sahip ve dayanıklı çeşitler açısından sorun yaşaması da rekabetini olumsuz yönde etkilemektedir. Örneğin; Türkiye'de yetiştiriciliği ve ihracatı yaygın olarak yapılan "Ziraat 900" çeşidi dünya pazarlarında önemini nispeten kaybetmektedir. Bu nedenle dayanıklı, pazar isteklerine uygun çeşitlerin yetiştiriciliğine geçilmesi, sahip olunan rekabet avantajının ve gücünün kaybedilmemesi açısından önemlidir. Bu kapsamda çeşit sslahı veya pazara uygun çeşitlerin geliştirilmesi ve sslah edilmiş bu çeşitlerin üreticiyle buluşturulması yönünde hızı adımlar atılması gerekmektedir. Bu bağlamda, pazara uygun kiraz çeşitlerinin üretime yönlendirilmesi açısından üreticilere gerek fidan desteği, gerekse çeşit değişiminden dolayı üretim aşamasında teşvik edici destekler sağlanması önem arz etmektedir. Bunun yanı sıra kiraz üreticilerine üretim tekniği ve pazarlama eğitimleri de verilmelidir.

Karşılaştırmalı üstünlüğün ve rekabet gücünün yüksek olması önemli olmakla birlikte, üstünlük durumunun istikrarlı bir seyir göstermesi de son derece önemlidir. Türkiye, yüksek düzeyde rekabet üstünlüğüne sahip olmasına rağmen bu üstünlük istikrarlı değildir. Rekabet avantajının korunmasında ürünün kaliteli, yüksek verimli ve sürdürülebilir nitelik ve nicelikte olması önemlidir. Bunun için sözleşmeli üretim modelinin yaygınlaştırılması ve üretici örgütlenmesinin etkin bir şekilde 
sağlanması ile ürünün gerek hastalık ve zararlılardan gerekse iklim değişiminin etkilerinden korunması gerekmektedir.

AB ülkeleri ve Rusya Federasyonu Türkiye için en önemli pazar durumundadır. Ancak mevcut üstünlüğün sürdürülebilir olması bakımından başta Uzak Doğu ülkeleri olmak üzere yeni pazarlara yönelmek ve bu pazarların isteklerine uygun ekonomik, politik ve sosyal stratejileri bir an önce hayata geçirmek gerekmektedir. Özellikle hedeflenen ülkelerle Türkiye lehine avantaj sağlayacak ikili anlaşmalar imzalanması için çaba harcanmalıdır.

Uluslararası ticarette yeni pazarlara ulaşmanın yanı sıra piyasada doğru, hızlı ve avantajlı olacak şekilde yer alabilmek, rekabet üstünlüğü için önemlidir. Maliyeti yüksek olsa da özellikle en hızlı ulaşım aracı olması nedeniyle havayolu taşımacılığının yaygınlaşması, rekabet gücünün korunmasını sağlayacaktır.

\section{Teşekkür}

$\mathrm{Bu}$ çalışma 2. Avrasya Tarım ve Doğa Bilimleri Kongresi'nde sunulmuştur.

\section{Kaynakça}

Akhtar, W., Akmal, N., Shah, H., Niazi, M. A., \& Tahir, A. (2013). Export competitiveness of Pakistani horticultural products. Pakistan J. Agric. Res. 26 (2), 87-96.

Anonim. (2014). Onuncu Kalkinma Planı 2014-2018 Bitkisel Üretim Özel İhtisas Komisyonu Raporu 2013. T.C. Kalkınma Bakanlığı, Yayın No: KB: 2877-ÖİK: 726, Ankara. tarim.kalkinma.gov.tr. Erişim tarihi: 28.03.2017.

Aynagöz Çakmak, Ö. (2005). AKÜ ve rekabet gücü: Türkiye tekstil ve hazır giyim endüstrisi üzerine bir uygulama. Ege Akademik Bakış Dergisi, Cilt: 5:1-2, 65-76.

Balassa, B. (1965). Trade liberalization and revealed comparative advantage. Manchester School of Economic and Social Studies, 33.

Çelik. Z., \& Gökkür, S. (2018, May). The role of cherry in fresh fruit production and trade Paper presented at the 1. International Agricultural Science Congress, Van, Turkey.

FAO. (2018). United Nations Food and Agriculture Organization, http://www.fao.org/faostat. Erişim tarihi: 28.02.2018.

Frohberg, K., \& Hartmann, M. (1997). Comparing measures of competitiveness. Institute of Agricultural Development in Central and Europe Discussion Paper, No:2, 7.

Laursen, K. (1998). Revealed comparative advantage and the alternatives as measures of international specialization. Danish Research Unit for Industrial Dynamics, DRUID Working Paper No:98-30.

Saçt, H., \& Dellal, İ. (2018, May). Revealed comparative advantage index: an application on cherry sector in Turkey and the competing countries Paper presented at the 1. International Agricultural Science Congress, Van, Turkey.

TRADE MAP. (2018). Trade statistics for international business development https://www.trademap.org. Erişim tarihi: 30.04.2018.

Vollrath, T. (1991). A theoretical evaluation of alternative trade intensity measures of revealed comparative advantage. Weltwirtschafliches Archiv, 127. 